\title{
The Evolving Manager Stereotype: The Effects of Industry Gender Typing on Performance Expectations for Leaders and their Teams
}

\author{
Susan F. Cabrera \\ Cornell University \\ Stephen J. Sauer \\ Clarkson University \\ Melissa C. Thomas-Hunt \\ University of Virginia
}

\begin{abstract}
This study examined how external evaluators' assessments of a management team and its leader are impacted by congruence between the leader's gender and the gender typing of the industry in which the team works. We experimentally tested our theory using industries that are either male typed or gender neutral, with teams led by male and female leaders. Results indicate that performance expectations for the team were more favorable when the leader's gender was congruent with the industry's gender typing, but expectations for the leader were not affected by gender congruence. These findings paradoxically suggest that evaluators form performance expectations for teams based upon individual characteristics of their leaders, even when these characteristics have no effect on the conscious assessments of the leaders themselves.
\end{abstract}

Although women now make up almost half of the U.S. workforce (U.S. Department of Labor, 2005), they still occupy only a minority of leadership positions in the businessworld, particularly among the biggest corporations. A recent study reports that women hold only $1.8 \%$ of the chief executive officer (CEO) positions in the Fortune 500, 16.4\% of corporate officer positions, $6.4 \%$ of the highest paid positions, and $9.4 \%$ of the highest clout positions (executive vice president and above). Furthermore, at the current rate of change, parity in corporate officer ranks will not be achieved for another 40 years (Catalyst, 2006).

Given these demographics, it is not surprising that leaders and managers have traditionally been perceived as possessing stereotypically male characteristics (Heilman, Block, Martell, \& Simon, 1989; Powell, Butterfield, \& Parent, 2002; Schein, 1973, 1975) or that women in leadership positions have been shown to receive lower performance evaluations than similarly qualifiedmen, particularly when the leadership context is male typed (Eagly, Karau, \& Makhijani, 1995; Eagly, Makhijani, \& Klonsky, 1992). However, in a handful of industries, women have achieved nearly equal representation within management. Although this progress has generally been limited to industries that are dominated by jobs historically associated with 
women and where women make up more than half of the employee base (Commission TUSEEO, 2003), it does suggest that traditional notions of managers as male are becoming less pervasive. In this research, we examine this evolving manager stereotype to gain a more nuanced understanding of how the "manager as male” (Heilman et al., 1989; Powell et al., 2002; Schein, 1973, 1975) concept either endures or dissipates at high levels within organizations.

The purpose of this study was twofold. First, in our examination of the effects of industry context on the evaluation of top managers, we extend research that has focused on low-level managerial positions (Garcia-Retamero \& Lopez- Zafra, 2006). Specifically, we examined how the gender typing of different industries affects the relative performance expectations for men and women leading executive teams. Whereas numerous industries can be characterized as male typed, very few industries can be unequivocally categorized as female typed. Even industries with a high percentage of female employees (e.g., health care) have a predominance of male managers at the executive level, making them gender neutral at best. Therefore, it is more useful to look at gender-typing categories that reflect this reality, that is, male and neutral typed, rather than male and female typed. Second, we move beyond work that investigates the effects of gender on performance expectations held solely for leaders to consider the potential effects on judgments of other members of the management team. If people hold different performance expectations for male and female leaders depending on the gender typing of the industry in which they work, the impact of these biases can have even greater reach if they also impact perceptions of entire teams and organizations. To address these second-order effects of gender typing and industry context, we draw upon research from upper echelons theory, which demonstrates that evaluators look to an organization's management team as a primary basis in evaluating the entire organization (Hambrick \& Mason, 1984), and "status leakage” research, which suggests that status diffuses across organizations such that the status of one party affects the status of other parties with whom they are affiliated (Podolny, 2005). We then use this theory to test and ultimately broaden the reach of role congruity theory (Eagly \& Karau, 2002), which has previously been largely confined to evaluation of individuals, as opposed to evaluation of teams.

\section{Occupational Gender Typing}

Pervasive gender segregation of the U.S. labor force by occupation, employer type, industry, and sector has been widely documented at virtually every economic level (for reviews, see Jacobs, 1995; Reskin, 1993). Within organizational hierarchies, women disproportionately occupy lower-level positions, whereas men disproportionately occupy management positions (Ragins \& Sundstrom, 1989; Wirth, 2001).Gender segregation persists even within management ranks, because women are disproportionately represented in staff positions instead of more highly paid and powerful line positions (Catalyst, 2006; Lyness \& Heilman, 2006). Researchers argue that the historical allocation of women into domestic labor and men into paid work has given rise to widely held stereotypes delineating how men and women should and do behave (Eagly \& Steffen, 1984). According to these stereotypes, women are considered to be communal, 
whereas men are considered to be agentic (Carli\&Eagly, 1999; Eagly\&Karau, 2002), suggesting that men are better suited for occupations that require characteristics such as instrumentality, ambition, and authority.

More specifically, this system of segregation and stereotyping results in gender typing, whereby certain jobs, occupations, and industries become descriptively associated with and prescriptively appropriate for either men or women. Gender typing of jobs is based on two elements (Davison \& Burke, 2000; Lyness \& Heilman, 2006; Ragins \& Sundstrom, 1989): the gender of the individuals who typically occupy the job (Cejka \& Eagly, 1999; Krefting, Berger, \& Wallace, 1978) and the gender association of the tasks required for the job (Heilman, 1983, 1995). Previous research has established that individuals tend to be evaluated more favorably when they occupy jobs that are typed consistently with their gender (Davison \& Burke, 2000). Much of this work has focused on individuals at lower levels within organizations, without giving adequate consideration to higher-level managers with established track records. In our research, we study how performance expectations for senior executives in different industries vary depending on the degree to which the industry is typed consistently with their gender.

\section{Managers as Male?}

Over the past 30 years, two streams of research have investigated the relationship between gender and managerial stereotypes. The first, Schein's (1973) "think manager — think male” research, has been replicated and extended to multiple populations both within the United States and internationally (Kunkel, Dennis, \& Waters, 2003; Norris \& Wylie, 1995; Schein, Mueller, Lituchy, \& Liu, 1996). This work demonstrates that the manager position has traditionally been male typed: Traits associated with a prototypical manager (e.g., decisiveness, persistence) are seen as highly consistent with qualities typically believed to be held by men but not by women. A second line of research has shown substantially similar results using a somewhat different methodology (Butterfield \& Grinnell, 1999; Powell \& Butterfield, 1979, 1989; Powell et al., 2002). In this research, participants completed a version of the Bem Sex Role Inventory (Bem, 1974, 1981), both for themselves and a good manager, and their scores were classified as androgynous, masculine, or feminine. Across numerous studies, this work has demonstrated that individuals view a good manager as possessing predominantly masculine characteristics (Powell et al., 2002).

However, within certain populations, there have been some cracks in the manager-asmale stereotype. Specifically, a few studies have shown that female participants from the United States no longer gender type the manager role as male (Brenner, Tomkiewicz, \& Schein, 1989; Schein, Mueller, \& Jacobson, 1989). Another study found that, although both men and women saw managers as possessing predominantly male characteristics, the preference for male characteristics was less in 1999 than in prior years, suggesting "both persistence and change in the nature of managerial stereotypes over time” (Powell et al., 2002, p. 188). Consistent with this evolving conceptualization of the typical manager, other research suggests that the category of 
manager may not be conceived of so broadly and that people make distinctions about the degree of male gender typing for particular managerial positions (Lyness \&Heilman, 2006). Specifically, line management positions, which involve direct responsibility for profit and loss, are seen as male typed, whereas staff management positions, which entail supporting roles, are seen as female typed.

In our research, we attempted to identify circumstances under which women may be fairly evaluated within line positions by focusing on senior management positions and considering how gender typing across different industries affects performance expectations for leaders and their teams. Over time, women have been successful in penetrating the management ranks of some industries more than others; as a result, the representation of women within management positions is not consistent across all sectors of the economy. For example, in fields such as marketing, advertising, and public relations, women now represent a majority of the employee base and approximately half of officials and managers (Commission TUSEEO, 2003), suggesting that these industries may now be considered gender neutral instead of male typed. This is in contrast to most other industries where senior women continue to be a statistical minority (Helfat, Harris, \& Wolfson, 2006). We argue that, given this substantial diversity in the representation of women across industries, it is now time to challenge further the traditional stereotype of managers as male by identifying particular industry contexts in which this stereotype no longer holds and in which women can therefore succeed in positions of power.

\section{Expectations for Leader Performance}

Role congruity theory of prejudice toward female leaders (Eagly \& Karau, 2002) provides a useful theoretical framework for our investigation of how male and female leaders may be perceived differently across varying industry contexts. The theory is an extension of social role theory, which seeks to explain the dearth of women in leadership positions in U.S. society (Eagly \& Karau, 2002; Ritter \& Yoder, 2004). According to social role theory, as a result of the allocation of women into domestic roles and men into paid work roles, women and men actively develop different skills, behaviors, and traits. These skills, behaviors, and traits are then adopted by society as normative and internalized by individuals into fundamental gender roles that are both descriptive and prescriptive in that they define how men and women typically do and should behave (Eagly, 1987). Importantly, the content of these gender roles is consistent with the social roles that men and women traditionally play, such that women are believed and expected to be communal, whereas men are believed and expected to be agentic (Eagly, 1987).

Building upon social role theory, role congruity theory suggests that prejudice against female leaders results from the perceived incongruity between the role requirements of a leader and the gender-role requirements of a typical woman (Eagly \& Karau, 2002).When forming expectations for the behavior and performance of a male leader, individuals combine the highly consistent requirements and expectations of the leader role with those of the male gender role. In contrast, when assessing female leaders, individuals must combine expectations that a leader will 
behave agentically with divergent expectations that a female will behave communally. This incongruity results in two potential forms of bias against female leaders: (a) lower expectations for women's potential for leadership because leadership ability is associated with being male and (b) lower evaluations of the female leader's actual behavior, even when she does fulfill the requirements of the leader role, because the agentic behavior required of the male-typed leader role is viewed as less appropriate for women than for men. Therefore, role congruity theory would predict that, in instances in which the leader role is male typed, female leaders will be subject to lower performance expectations and lower evaluations than comparable male leaders—a prediction that is empirically well supported (Eagly \& Karau, 2002).

For the first time in history, women have achieved approximate parity within the management ranks of a handful of industries in the United States (Commission TUSEEO, 2003). As a result, these industries may reasonably be characterized as gender neutral, in particular if the tasks associated with the leader role in these industries are both male and female typed. According to role congruity theory, within such gender-neutral industries, men and women will be perceived as equally congruent with the leader role. As a consequence, performance expectations for leaders should be less affected by leader gender in gender-neutral industries than in male-typed industries.

Hypothesis 1: Leader gender will have a greater effect on the performance expectations held for leaders in male-typed industries than in gender-neutral industries, such that in male-typed industries performance expectations held for male leaders will be higher than those held for female leaders.

\section{Expectations for Team Performance}

To date, empirical research investigating role congruity theory has largely focused on evaluations of the individual. Further, when the gender composition of a management team is mixed, as in many real-world situations, the gender of some team members will be congruent while others are incongruent with the industry gender typing. Given these factors, predictions suggested by role congruity theory about the interactive effects of leader gender with industry gender typing on performance expectations for teams are less clear-cut than those for individual leaders. For instance, if evaluators focus on the leader when they make their assessments of the team, then the predictions suggested by role congruity theory are consistent with those for the leader. That is, male-led teams would be expected to outperform female-led teams in a maletyped industry, but not in a gender-neutral industry. If, however, evaluators make an overall team assessment that focuses on all members of the team equally, then theory would suggest that team gender composition must be considered in light of industry gender typing. In a male-typed industry, a mixed-gender team might be perceived as subordinate to an all-male team and superior to an all-female team. However, in a gender-neutral industry, a mixed-gender team might be perceived as more congruent than either an all-male or an all-female team, because members of each gender can contribute different qualities required for managing in such an 
industry. In this instance, a mixed-gender team would be expected to yield the highest performance.

To choose between these conflicting predictions, we looked at research concerning the focus of evaluators' assessments of teams. Recent research in upper echelons theory (Flynn \& Staw, 2004; Hambrick \& Mason, 1984; Higgins \& Gulati, 2006) has studied this issue at the organizational level, and results suggest that evaluators look to an organization's management team as a primary basis in evaluating the entire organization. Furthermore, status can leak from one organizational level to another; in other words, the status of an individual can influence the status of the team with whom they are affiliated (Podolny, 2005). A recent empirical investigation examining the effects of CEO status on top management team compensation found that leader status does in fact affect the status of the management team (Graffin, Wade, Porac, \& Mc- Namee, 2008). Another study showed a close correlation between a leader's reputation and that of his or her organization (Davies \& Mian, 2006). Taken together, these findings suggest that evaluators place the greatest emphasis on a team's leader when assessing the team. In that case, congruence between the leader's gender (and not team gender composition) and industry gender typing will influence expectations of the team's performance. Thus, our predictions for expected team performance are consistent with our predictions for expected leader performance.

Hypothesis 2: Leader gender will have a greater effect on the performance expectations held for teams in male-typed industries than in gender-neutral industries, such that in male-typed industries performance expectations held for male-led teams will be higher than those held for female-led teams.

\section{Method}

\section{Participants}

Participants for this study were 91 graduate students from a large university in the eastern United States. They were paid \$10 in cash and entered into a lottery for a \$200 gift certificate in exchange for their participation. The study was conducted in an online format in which participants were e-mailed and asked to click on a link to a Web site that contained all of the study directions, materials, and questions. We recruited participants from the graduate business school, and the majority of our participants (75.8\%) were students in the Masters of Business Administration (MBA) program. We chose to sample from this pool of participants because they had the requisite knowledge and qualifications to evaluate the offering memoranda and project proposals used in our experimental task. In addition, they were likely to have some business experience prior to beginning their graduate work (69.7\% reported having more than 3 years of experience) and, thus, reasonably reflect attitudes of the managers of contemporary American organizations. Finally, participants in this pool were likely to have a greater degree of familiarity than other potential populations with the gender composition of each of the industries we used in our study. 
The participants comprised 60 males and 31 females. They were predominantly Caucasian (50.5\%) or Asian/Pacific Islander (38.5\%), with Africans, Hispanics or Latinos, African Americans and other non-specified races constituting 3.3\%, 2.2\%, 1.1\%, and 4.4\%, respectively. The participants were between 20 and 38 years old $(M=28.0$ years, $S D=3.21)$.

\section{Selection of Industries}

Although male-dominated industries abound, there are virtually no business sectors dominated by women at the senior executive level (Helfat et al., 2006).Given this methodological limitation and social reality, we examined the impact of congruence in one maletyped and one gender-neutral industry. Based on actual gender composition data, we selected an initial list of seven industries. From this list, we made our final selection based on a pretest of MBA students' perceptions of the industries' gender composition. In the pretest, a separate sample of 104 MBA students were asked to indicate the mix of men and women senior executives in each of the seven industries. Pretest participants estimated the private equity industry as comprising $84.7 \%$ men and $15.3 \%$ women senior executives and the marketing consulting industry as comprising $54.9 \%$ men and $45.1 \%$ women senior executives. Based on these responses, we selected private equity as our male-typed industry and marketing consulting as our gender-neutral industry.

The pretest results were generally consistent with both actual industry data and the perceptions of our main study participants. Specifically, in 2000, women made up approximately $9 \%$ of management-track professionals in the venture capital sector (an industry that is closely related to private equity), down from 10\% in 1995 (Brush, Carter, Gatewood, Greene, \& Hart, 2004), whereas in 2006 they made up approximately $48 \%$ and 38\% of officials and managers at marketing research firms and management consulting firms, respectively (Commission TUSEEO, 2006). Further, our actual study participants estimated that senior executives in the private equity industry comprise $83.3 \%$ men and $16.7 \%$ women and senior executives in the marketing consulting industry comprise $54.2 \%$ men and $45.8 \%$ women. To explicitly confirm that private equity was perceived as having more male-typed tasks than marketing consulting, we conducted a separate pretest with 39 individuals currently enrolled in a graduate business elective. Using a 7-point Likert-type scale (anchored by $1=$ mostly female-typed tasks and $7=$ mostly male-typed tasks), we asked participants to "indicate the degree to which the following industries are associated with male- or female-typed tasks" for eight industries, including private equity and marketing consulting. Participants reported that the private equity industry had significantly more male-typed tasks $(M=5.77, S D=0.96)$ than the marketing consulting industry $(M=3.59, S D=1.09), t(38)=10.19, p<.01$.

\section{Designing and Procedure}

The study used a 2 (senior partner gender) $\times 2$ (gender typing of industry: male [private equity] or neutral [marketing consulting]) between-subjects experimental design in which 
participants were randomly assigned to one of four conditions. We manipulated senior partner gender by changing the senior partner's first name (Elizabeth or James). The other two management team members were men in all conditions. Recognizing that subordinate team members' gender is also likely to impact perceptions of the leader and team, our focus on leader gender effects led us to control for the subordinate composition by choosing the gender configuration most often reflected within executive teams in the business world, that is, primarily men. We manipulated industry by varying the decision scenario presented to the participants.

We told participants that the study was part of a broader research project aimed at gaining a better understanding of the mechanisms individuals use for making complex decisions. Given recent criticism of stereotyping research as lacking in realism (Landy, 2008), we chose realworld business contexts for our industry conditions and developed realistic materials reflective of those used by actual industry professionals. In the male-typed industry condition, we asked participants to play the role of associate at an investment fund and to evaluate the management team of a private equity fund in which their firm is considering an investment. A private equity fund is a specialized type of investment vehicle used for making investments in equity securities. They typically raise capital every 3 to 5 years from high-net-worth individuals and institutional investors such as diversified investment funds, pension funds, and financial services companies. In the neutral-typed industry condition, we asked participants to play the role of associate at a large U.S. consumer products company and evaluate the management team of a marketing consulting firm that their company is considering hiring to manage the launch of a new consumer product.

It is typical business practice for firms in the private equity industry to prepare an offering memorandum that is distributed to potential investors and used as an initial basis for screening firms. Similarly, corporate clients seeking marketing consulting services frequently send a request for proposals to potential consulting firms who respond with a project proposal delineating their qualifications. Therefore, we presented each participant with either a private equity offering memorandum or a marketing consulting project proposal said to be prepared by a three-member management team. The memoranda and project proposals were each six pages in length and detailed, among other things, the company's strategy, history, and key success factors, as well as some limited financial data on the company's track record, including equity value returned and internal rate of return for the private equity firm and number of projects managed, and return on investment for the marketing consulting firm. Although the materials were tailored to the respective industry, we sought to maintain as much consistency as possible in the type and quantity of the information provided across conditions, as well as in the overall quality of the firm.

We also provided biographical information for each of the three members of the management team, composed of one senior partner and two junior partners. This information included each manager's title, length of time with the firm, prior employment history, and 
education. The only difference between the biographies across industry condition was the name of the firm for whom the managers previously worked, and the only difference across gender conditions was the first name of the senior partner. In all conditions, the education and previous employers of the management team were intentionally prestigious, providing a conservative test of our hypotheses, because it has been empirically demonstrated that gender bias is greater when evaluators are presented with ambiguous or insufficient information about the quality of performance (Heilman, 1995, 2001; Heilman, Wallen, Fuchs, \& Tamkins, 2004; Nieva \& Gutek, 1980; Tosi \& Einbender, 1985).

We instructed participants to determine performance expectations for the senior partner and the management team, which they would convey to their boss. After submitting their responses, participants were asked to complete a short survey identical to the pretest, in which they indicated the mix of men and women senior executives in a series of industries including private equity and marketing consulting.

\section{Measures}

Expected leader performance. This measure was made up of eight items, each of which was measured on a 9-point Likert-type scale. The first item measured participants' general assessment of the senior partner's expected level of performance. The other seven items measured the degree to which participants believed the senior partner possessed specific skills, including decision-making, interpersonal relations, leadership, oral communication, problem solving, planning, and financial skills. Cronbach’s alpha for the measure was 0.92.

Expected team performance. This measure included two items, both of which were measured using a 9-point Likert-type scale. In the first item, we asked participants, "If you were to review eight private equity/marketing consulting offering memoranda, how likely it is that this one would compare favorably to the others?” In the second item, we asked participants to indicate the likelihood that the firm would deliver "home run” results. Cronbach's alpha for this measure was 0.63 . Although inter item reliability is relatively low, analyzing each of the items separately produced substantively similar results.

\section{Results}

To test our hypotheses, we conducted 2-way analyses of variance (ANOVAs) with leader gender and industry gender typing as factors and then conducted simple effects tests comparing the ratings of the leader and team by gender of the leader within each industry condition. A onetailed test was used for the simple effects tests in the male-typed industry for both hypotheses because our hypotheses specifically predicted that the male leader and male-led team would receive higher ratings than the female leader and female-led team in the male-typed private equity industry. Our hypotheses did not make specific one-way predictions for the gender-neutral industry, so we used two-tailed tests for those comparisons. We also ran analyses of covariance (ANCOVAs), including participant gender as a control variable, an ANOVA including 
participant gender as an independent variable, and separate ANCOVAs including race and age as control variables. Because none of these control variables had any significant effect on the results in any of the analyses, we have reported only the ANOVA results excluding controls.

Table 1 provides a summary of the ANOVA results, and Table 2 reports the results of the simple effects tests for both dependent variables.

Hypothesis 1, which concerned assessments of the leader, was not supported. Although the two-way ANOVA

Table 1

Analysis of Variance for Effects of Leader Gender and Industry Gender Typing on Expected Leader and Team Performance

\begin{tabular}{lrcc}
\hline Source & $d f$ & $F$ & $p$-value \\
\hline Expected leader performance scale & & & \\
$\quad$ Industry gender typing & 1 & 1.50 & .22 \\
$\quad$ Leader gender & 1 & 1.25 & .27 \\
$\quad$ Industry gender typing $\times$ leader gender & 1 & 5.08 & .03 \\
$\quad$ Error & 87 & $(1.29)$ & \\
Expected team performance scale & & & \\
$\quad$ Industry gender typing & 1 & 3.19 & .08 \\
$\quad$ Leader gender & 1 & 0.05 & .83 \\
$\quad$ Industry gender typing $\times$ leader gender & 1 & 4.48 & .04 \\
$\quad$ Error & 87 & $(1.68)$ & \\
\hline
\end{tabular}

Note. Values enclosed in parentheses represent mean square errors.

Table 2

Simple Effects Tests Comparing Expectations for Leader and Team Performance Within Each Industry

\begin{tabular}{|c|c|c|c|}
\hline Dependent variable & Mean $(S D)$ & $t$ & p-oalue \\
\hline \multicolumn{4}{|l|}{ Expected leader performance } \\
\hline \multicolumn{4}{|l|}{ Private equity (male-typed) } \\
\hline Female leader $(n=25)$ & $7.31(1.05)$ & & \\
\hline Male leader $(n=23)$ & $7.58(1.03)$ & & \\
\hline Effect of leader gender & & .90 & $.19^{\mathrm{a}}$ \\
\hline \multicolumn{4}{|c|}{ Marketing consulting (gender-neutral) } \\
\hline Female leader $(n=24)$ & $7.56(.78)$ & & \\
\hline Male leader $(n=19)$ & $6.75(1.63)$ & & \\
\hline Effect of leader gender & & 2.14 & $.04^{\mathrm{b}}$ \\
\hline \multirow{2}{*}{\multicolumn{4}{|c|}{ Expected team performance }} \\
\hline & & & \\
\hline Female leader $(n=25)$ & $5.06(1.28)$ & & \\
\hline Male leader $(n=23)$ & $5.70(1.14)$ & & \\
\hline Effect of leader gender & & 1.82 & $.04^{\mathrm{a}}$ \\
\hline \multicolumn{4}{|c|}{ Marketing consulting (gender-neutral) } \\
\hline Female leader $(n=24)$ & $6.13(1.05)$ & & \\
\hline Male leader $(n=19)$ & $5.61(1.72)$ & & \\
\hline Effect of leader gender & & 1.22 & $.22^{\mathrm{b}}$ \\
\hline
\end{tabular}

showed a significant interaction effect on mean expected leader performance, $F(1,87)=5.08$, $p<.05$, the tests of the means underlying the interaction showed that the effects were in the opposite direction of our predictions. Specifically, in the male-typed industry, there was no significant difference between performance ratings for the male and female leader, $M($ male $)=$ 
7.58, $M($ female $)=7.31, t(46)=0.90, n s$, one-tailed, whereas in the gender-neutral marketing consulting industry, the expected leader performance rating for the female leader was significantly higher than the ratings for the male leader, $M($ female $)=7.56, M($ male $)=6.75, t(41)=$ 2.14, $p=.04$, two-tailed.

In contrast, Hypotheses 2 was supported. The ANOVA revealed a significant interaction on mean expected team performance, $F(1,87)=4.48, p<.05$. Further, a simple effects test revealed that, in the male-typed private equity industry team, performance ratings for the maleled team were significantly higher than ratings for the female led team, $M$ (male) $=5.70, M$ (female) $=5.06, t(46)=1.82, p=.04$, one-tailed. In the gender-neutral industry, as predicted, there was no significant difference between the expected team performance ratings for femaleand male led teams, $M$ (female $)=6.13, M$ (male $)=5.61, t(41)=1.16, n s$, two-tailed.

\section{Discussion}

As women have approached parity in the executive leadership of a handful of industries in the United States, the gender typing of these industries has shifted from the traditional male model to one that is more gender neutral in nature. In this research, we experimentally investigated the impact of such a shift upon the relative performance expectations held for both male and female leaders and for the teams they lead. Surprisingly, we found that congruence between leader gender and industry gender typing impacts assessments of a team's performance, but does not impact assessments of leaders themselves. Clearly, this paradoxical pattern of findings warrants further discussion.

As noted above, paired comparisons showed that in the gender-neutral industry, ratings of the female leader were higher than those of the male leader, a finding not previously supported in past research, whereas in the male-typed industry, there was no significant difference in ratings of the male and female leaders. On the face of it, this pattern is surprising in that it appears to suggest an overall advantage for female leaders. Although this may be the case, we suggest possible alternative explanations. First, the simple presence of a woman in a position typically held by men may have resulted in gender being particularly salient, triggering a social desirability effect in which participants sought to avoid appearing prejudiced against women leaders, irrespective of their true opinions (Paulhus, 1984). As a result, the performance expectations for female leaders may have been artificially inflated. Second, as noted above, all of the members of the management teams described in the stimulus materials were highly qualified and had clearly been successful in the past. Previous research has established that, when women are demonstrably successful, they are less likely to be evaluated based upon negative stereotypes (Heilman, 1995; Heilman et al., 2004). Given this, we believe that expected bias against the female leader in the male-typed condition of our experiment may have been muted.

Finally, the higher ratings of the female leader in the gender-neutral industry may have been partially due to the task typing of the particular industry we chose. We noted earlier that we 
conducted a pretest of industry task-typing to ensure that private equity, relative to marketing consulting, had more male-typed tasks than female-typed tasks. That pretest also showed that the gender task-typing mean for the marketing consulting industry was significantly different from the midpoint, $t(38)=2.34, p<.05$, indicating that it was perceived to be populated with more female-typed tasks than gender-neutral tasks. Thus, although marketing consulting is gender neutral from a numerical standpoint, it is possible that, due to the industry's task typing, some participants perceived the female leader as having a performance advantage over the male leader.

With respect to performance expectations for the team, paired comparisons demonstrated a different pattern. When people are asked to evaluate a team rather than a single individual, we would expect the social desirability effects discussed above to drop away as gender becomes somewhat less salient. Therefore, it is not surprising that assessments of the male-led team in the male-typed industry were significantly higher than for the female-led team, whereas in the gender-neutral industry, there was no significant difference in expected performance for the two teams. These findings suggest that, when making an assessment of the team, participants largely focused on the gender congruency of the leader and the industry, and this influenced expectations for team performance. In other words, the notion that male leaders and, by association, male-led teams will outperform women leaders and women-led teams is no longer applicable in all situations. Instead, as more women move into management positions within specific industries, these stereotypes are evolving to be dependent upon the industry context in which they are applied.

\section{Theoretical and Practical Implications}

This research extends existing theory in several ways. First, our work extends role congruity theory beyond its prior focus on individual leaders to consider how gender typing of industries and leader roles can influence expectations for teams. In addition, by testing the impact of congruency in a gender-neutral industry, our research demonstrates that the theory can be used to begin to identify circumstances in which female leaders may not be subject to prejudice in evaluations of their performance. Finally, our findings extend upper echelons research and provide support for status leakage arguments by suggesting that at lower levels within organizations, the status and resulting performance expectations of a team are impacted by assessments of the team's leaders. Specifically, we demonstrate that the tendency of evaluators to look at top managers when assessing an entire organization carries over to the team level; that is, when assessing teams within an organization, evaluators focus largely on the performance of the individual leaders of those teams.

From a managerial perspective, this research demonstrates the power of stereotypes concerning what kinds of people should lead organizations in what kinds of industries. In addition, it suggests that, as more women move into certain sectors of our economy, stereotypes may be evolving, resulting in changes in the relative expectations for performance by men and women in management positions. Could this be one avenue toward equality in the leadership 
positions of our society? Our answer is: maybe. Although our results are somewhat promising, the great majority of industries remain male dominated and male typed; further, change is slow in coming. Another issue is the tautological relationship between performance expectations and executive advancement. To have more neutral or no gender stereotypes about managers in a given industry, the gender composition of that industry needs to approach parity. However, as long as performance expectations remain low for women-led teams in most industries, it will be more difficult for women to make progress in penetrating the management ranks.

\section{Limitations and Future Research Directions}

Our findings, as well as some of the limitations of our study, suggest several other interesting avenues for future work. First, the paradoxical nature of our findings - in which leader gender congruency with industry gender typing appears to affect evaluations of the team but not the leader - suggests the need for further research investigating these questions. In particular, the field needs research that can successfully eliminate potentially confounding effects such as social desirability and status. Although our team findings clearly support our hypotheses suggested by role congruity theory, a confounding factor may have also contributed to their pattern and strength. Like role congruity theory, status characteristics theory also predicts that women in business settings and in particular in management roles (both of which are typically male typed) will be subject to lower performance expectations than men and therefore receive lower performance evaluations than men (Ridgeway, 1997). This status effect would be expected to operate in particular in situations where gender is highly salient, such as when a task is particularly gender typed or where a group comprises both men and women and therefore gender is useful as a differentiating attribute (Mullen, 1991; Taylor, 1981). The experimental condition in which participants were asked to evaluate a team composed of a female leader and two male followers working in a male-typed industry would present just such a salient context. In this instance, the female leader was not only incongruent with the gender typing of the industry, but she was also engaged in a status violation by supervising two higher-gender status men. This status violation alone would be expected to result in lower ratings for the female leader and her team. In contrast, the all-male team operating in the male-typed industry was neither incongruent nor engaged in a status violation and therefore would be expected to garner higher ratings. In sum, the fact that our pattern of findings in the male-typed industry could be equally explained by status effects or role congruity effects suggests the need for further research aimed at separating these factors. A logical first step in accomplishing this might be conducting a study similar to ours that eliminates the potential for a status violation by varying the gender composition of the subordinate team members. Such a study could also eliminate any explanation of the findings based upon other social identity dynamics.

Second, further research is required to determine to what degree the status and performance assessments of leaders will leak into parallel assessments of their teams. In this research, participants were presented with a management team composed of only three individuals, which may have increased the weight that individuals placed on their assessment of 
the leader when considering the likely performance of the team. In evaluations of larger, more complex organizations where greater information is provided, it is not clear that this relationship would hold.

Third, our experimental design incorporated only two industries, one of which was highly male typed and one of which was gender neutral. It is possible that our results were due to specific idiosyncratic characteristics of the private equity and marketing consulting industries or by the degree of gender typing of each. To have confidence in the generalizability of our results to other industries, it would be appropriate to explore the effects of congruence between industry gender typing and leader gender in other industries, including those that aremoremoderately male typed. Also, to the extent that there are industries that are truly female dominated at the senior executive level (or perhaps by looking beyond the U.S. context), research should explore whether we find the same pattern of effects in these sectors.

Fourth, because the leader in our study design was evaluated only in the context of a team, we cannot know whether the interactive effects of leader gender and industry gender typing would be the same if the leader were not a member of a team. It is possible that individuals (male or female) who lead a team are perceived differently from individuals who do not have to work with a team. For example, teamwork itself may be gender typed, which could potentially impact the performance expectations for a leader. Fifth, as mentioned above, in our study we intentionally presented managers of high quality with excellent educational and employment histories. Previous empirical research demonstrated that gender bias is greater when evaluators are presented with ambiguous or insufficient information about performance (Heilman, 1995, 2001; Heilman et al., 2004; Nieva \& Gutek, 1980; Tosi \& Einbender, 1985); thus, our approach represents a conservative test of our hypotheses. However, only additional research can determine whether our findings would generalize to leaders and management teams of ambiguous or even poor quality.

Sixth, our study was experimental in nature, using subjects who were MBA students evaluating fictional materials rather than practicing managers evaluating real management teams. Although we intentionally chose MBA students because they were more likely to be experienced in evaluating business proposals similar to our stimulus materials, we cannot be sure that they had such experience, and they may have evaluated the leaders and teams differently than would actual managers. We do note, however, that, unlike much stereotyping research, which has been criticized for lack of real-world validity (Landy, 2008), in our study, the ratings context and the materials used were modeled after actual industry practices and therefore were quite realistic. Finally, we asked participants to indicate their expectations for leader and team performance, rather than having them evaluate actual behavior. Therefore, the current research does not tell us whether gender congruency-based differences in performance expectations actually translate into differences in real-world behavior. For example, would venture capitalists be less likely to invest in a cosmetics company led by a man? Existing research demonstrating that low performance expectations can translate into fewer opportunities to participate in groups (Meeker 
\& Weitzel- O’Neill, 1977), a diminished ability to influence others (Sheldon, Thomas-Hunt, \& Proell, 2006; Thomas-Hunt \& Phillips, 2004), and fewer job interviews (Bertrand \& Mullainathan, 2004) suggests that a link between expectations and action is likely. Given that the real-world implications of these questions are far from trivial, more research in this area is warranted. Despite the above limitations, this study represents a first step in understanding the impact of relatively recent changes in the gender composition of various industries in the United States upon evaluations of female and male leaders and their teams. Specifically, we investigated how assessments of a management team and its leader are impacted by congruence between the leader's gender and the gender typing of the industry in which the team works. Our paradoxical finding that such congruence has a significant effect upon the performance expectations held for teams but not their leaders both extends role congruity theory and upper echelons theory and opens multiple new avenues for future research.

\section{References}

Bem, S. L. (1974). The measurement of psychological androgyny. Journal of Consulting and Clinical Psychology, 42, 155-

162.

Bem, S. L. (1981). Bem Sex Role Inventory: Professional manual. Palo Alto, CA: Consulting Psychologists Press.

Bertrand, M., \& Mullainathan, S. (2004). Are Emily and Greg more employable than Lakisha and Jamal? A field experiment on labor market discrimination. American Economic Review, 94, 991-1013.

Brenner, O. C., Tomkiewicz, J., \& Schein, V. E. (1989). The relationship between sex-role stereotypes and requisite management characteristics revisited. Academy of Management Journal, 32, 662-669.

Brush, C. G., Carter, N., Gatewood, E., Greene, P., \& Hart, M. (2004). Gatekeepers of venture growth: A Diana Project report on the role and participation of women in the venture capital industry. Kansas City, MO: Ewing Marion Kaufmann Foundation.

Butterfield, D. A., \& Grinnell, J. P. (1999). “Re-viewing” gender, leadership, and managerial behavior. Do three decades of research tell us anything? In G. N. Powell (Ed.), Handbook of gender and work (pp. 223-238). Thousand Oaks, CA: Sage.

Carli, L. L., \& Eagly, A. H. (1999). Gender effects on social influence and emergent leadership. In G. N. Powell (Ed.), Handbook of gender and work (pp. 203-222). Thousand Oaks, CA: Sage.

Catalyst. (2006). 2005 Catalyst census of women corporate officers and top earners of the Fortune 500. New York: Catalyst.

Cejka, M. A., \& Eagly, A. H. (1999). Gender-stereotypic images of occupations correspond to the sex segregation of employment. Personality and Social Psychology Bulletin, 25, 413-423.

Commission TUSEEO. (2003). Occupational employment in private industry by race/ethnic group/sex and by industry, United 
States, 2003. Retrieved Aug. 26, 2006, from http://www.eeoc.gov/stats/jobpat/2003/national.html.

Commission TUSEEO. (2006). Occupational employment in private industry by race/ethnic group/sex and by industry, United

States, 2006. Retrieved Dec. 12, 2008, from http://www.eeoc.gov/stats/jobpat/2006/nac5/index.html.

Davies, G., \& Mian, T. (2006). The reputation of the leader and that of the organization: Evidence from the business of politics. Atlanta, GA: Academy of Management Proceedings.

Davison, H. K., \& Burke, M. J. (2000). Sex discrimination in simulated employment contexts: Ameta-analytic investigation. Journal of Vocational Behavior, 56, 225-248.

Eagly, A. H. (1987). Sex differences in social behavior: A socialrole interpretation. Hillsdale, NJ: Erlbaum.

Eagly, A. H., \& Karau, S. J. (2002). Role congruity theory of prejudice toward female leaders. Psychological Review, 109, 573-598.

Eagly, A. H., Karau, S. J., \&Makhijani, M. G. (1995). Gender and the effectiveness of leaders-A meta-analysis. Psychological Bulletin, 117, 125-145.

Eagly, A. H., Makhijani, M. G., \& Klonsky, B. G. (1992). Gender and the evaluation of leaders—A meta-analysis. Psychological Bulletin, 111, 3-22.

Eagly, A. H., \& Steffen, V. J. (1984). Gender stereotypes stem from the distribution of women and men into social roles. Journal of Personality and Social Psychology, 46, 735-754.

Flynn, F. J., \& Staw, B. M. (2004). Lend me your wallets: The effect of charismatic leadership on external support for an organization. Strategic Management Journal, 25, 309-330.

Garcia-Retamero, R.,\&Lopez-Zafra, E. (2006). Prejudice against women in male-congenial environments: Perceptions of gender role congruity in leadership. Sex Roles, 55, 51-61.

Graffin, S. D.,Wade, J. B., Porac, J. F.,\&McNamee, R. C. (2008). The impact of CEO status diffusion on the economic outcomes of other senior managers. Organization Science, 19, 457-474.

Hambrick, D. C., \& Mason, P. A. (1984). Upper echelons-The organization as a reflection of its top managers. Academy of Management Review, 9, 193-206.

Heilman, M. E. (1983). Sex bias in work settings: The lack of fit model. In L. Cummings \& B. Staw (Eds.), Research in organizational behavior (Vol. 5, pp. 269-298). Greenwich, CT: JAI Press.

Heilman, M. E. (1995). Sex stereotypes and their effects in the workplace:What we know and what we don’t know. Journal of Social Behavior and Personality, 10(6), 3-26.

Heilman, M. E. (2001).Description and prescription:Howgender stereotypes prevent women’s ascent up the organizational ladder. Journal of Social Issues, 57, 657-674. 
Heilman, M. E., Block, C. J., Martell, R. F., \& Simon, M. C. (1989). Has anything changed? Current characterizations of men, women, andmanagers. Journal of Applied Psychology, 74, 935-942.

Heilman, M. E., Wallen, A. S., Fuchs, D., \& Tamkins, M. M. (2004). Penalties for success: Reactions to women who succeed at male gender-typed tasks. Journal of Applied Psychology, 89, 416-427.

Helfat, C. E., Harris, D., \& Wolfson, P. J. (2006). The pipeline to the top: Women and men in the top executive ranks of U.S. corporations. Academy of Management Perspectives, 20(4), 42-64.

Higgins, M. C., \& Gulati, R. (2006). Stacking the deck: The effects of top management backgrounds on investor decisions. Strategic Management Journal, 27, 1-25.

Jacobs, J. A. (1995). Gender inequality at work. Thousand Oaks, CA: Sage.

Krefting, L. A., Berger, P. K., \& Wallace, M. J. (1978). Contribution of sex distribution, job content, and occupational classification to job sex-typing—2 studies. Journal of Vocational Behavior, 13, 181-191.

Kunkel, A., Dennis, M. R., \& Waters, E. (2003). Contemporary university students’ ratings of characteristics of men, women, and CEOs. Psychological Reports, 93, 1197-1213.

Landy, F. J. (2008). The tenuous bridge between research and reality: The importance of research design in inferences regarding work behavior. In E.

Borgida \& S. T. Fiske (Eds.), Beyond common sense: Psychological science in the courtroom (pp. 341-352). Malden MA: Blackwell.

Lyness, K. S., \& Heilman, M. E. (2006).When fit is fundamental: Performance evaluations and promotions of upper-level female and male managers. Journal of Applied Psychology, 91, 777-785.

Meeker, B. F., \& Weitzel-O’Neill, P. A. (1977). Sex-roles and interpersonal-behavior in task-oriented groups. American Sociological Review, 42, 91-105.

Mullen, B. (1991). Group composition, salience, and cognitive representations—The phenomenology of being in a group. Journal of Experimental Social Psychology, 27, 297-323.

Nieva, V. F., \& Gutek, B. A. (1980). Sex effects on evaluation. Academy of Management Review, 5, 267-276.

Norris, J. M., \& Wylie, A. M. (1995). Gender stereotyping of the managerial role among students in Canada and the United States. Group \& Organization Management, 20, 167-182.

Paulhus, D. L. (1984). Two-component models of socially desirable responding. Journal of Personality and Social Psychology, 46, 598-609.

Podolny, J. M. (2005). Status signals: A sociological study of market competition. Princeton, NJ: Princeton University Press.

Powell, G. N., \& Butterfield, D. A. (1979). Good manager- Masculine or androgynous. Academy of Management Journal, 22, 395-403. 
Powell, G. N., \& Butterfield, D. A. (1989). The good manager — Did androgyny fare better in the 1980s. Group \& Organization Studies, 14, 216-233.

Powell, G. N., Butterfield, D. A., \& Parent, J. D. (2002). Gender and managerial stereotypes: Have the times changed? Journal of Management, 28, 177-193.

Ragins, B. R., \& Sundstrom, E. (1989). Gender and power in organizations: A longitudinal perspective. Psychological Bulletin, 106, 51-88.

Reskin, B. (1993). Sex segregation in the workplace. Annual Review of Sociology, 19, 241-270.

Ridgeway, C. L. (1997). Interaction and the conservation of gender inequality: Considering employment. American Sociological Review, 62, 218-235.

Ritter, B. A., \& Yoder, J. D. (2004). Gender differences in leader emergence persist even for dominant women: An updated confirmation of role congruity theory. Psychology of Women Quarterly, 28, 187-193.

Schein, V. E. (1973). Relationship between sex role stereotypes and requisite management characteristics. Journal of Applied Psychology, 57, 95-100.

Schein, V. E. (1975). Relationships between sex-role stereotypes and requisite management characteristics among female managers. Journal of Applied Psychology, 60, 340-344.

Schein, V. E.,Mueller, R.,\&Jacobson,C. (1989). The relationship between sex-role stereotypes and requisite management characteristics among college-students. Sex Roles, 20, 103- 110.

Schein, V. E., Mueller, R., Lituchy, T., \& Liu, J. (1996). Think manager-think male: A global phenomenon? Journal of Organizational Behavior, 17, 33-41.

Sheldon, O. J., Thomas-Hunt,M. C.,\&Proell, C. A. (2006).When timeliness matters: The moderating effect of status on behavioral reactions to time delay within work interactions. Journal of Applied Psychology, 91, 1385-1395.

Taylor, S. E. (1981). A categorization approach to stereotyping. In D. Hamilton (Ed.), Cognitive processes in stereotyping and intergroup behavior (pp. 83-114). Hillsdale, NJ: Erlbaum.

Thomas-Hunt, M. C., \& Phillips, K. W. (2004). When what you know is not enough: Expertise and gender dynamics in task groups. Personality and Social Psychology Bulletin, 30, 1585-1598.

Tosi,H. L.,\&Einbender, S. W. (1985). The effects of the type and amount of information in sex-discrimination research-A meta-analysis. Academy of Management Journal, 28, 712- 723.

U.S. Department of Labor. (2005). Statistics and data. Retrieved Aug. 26, 2006, from http://www.dol.gov/wb/stats/main.htm.

Wirth, L. (2001). Breaking through the glass ceiling: Women in management. Geneva, Switzerland: International Labour Office. 